\title{
Genetic and chemical methods of ascertaining aflatoxigenicity give discordant results: A Case of Aspergillus species from Eastern Kenya
}

Micah Kipkemboi Lagat

Egerton University

Faith Jebet Toroitich

Egerton University

Huxley Mae Makonde

Technical University of Mombasa

Meshack Amos Obonyo ( $\square$ obonyom@gmail.com )

Egerton University

\section{Research Article}

Keywords: aflatoxin, non-aflatoxigenic, aflatoxigenicty, Aspergillus section Flavi, Dichlorvos-ammonia.

Posted Date: March 19th, 2021

DOl: https://doi.org/10.21203/rs.3.rs-267999/v1

License: (a) (i) This work is licensed under a Creative Commons Attribution 4.0 International License. Read Full License 


\section{Abstract}

Background: Aflatoxins (AFs) are poisonous compounds produced by species of fungi belonging to the genus Aspergillus mainly A. flavus and A. parasiticus. However, there are some members of these species that do not produce toxins and have since become of interest for use in Biological Control programs. The species that produce AFs are believed to have clusters of aflatoxin-associated genes that confer aflatoxigenicity. However, recent findings suggest that the presence of aflatoxin genes may not imply aflatoxin production capability. We therefore examined the extent to which the presence or absence of aflatoxin-associated genes (genetic) infers aflatoxigenicity using the Dichlorvos-Ammonia (chemical) method as reference.

Results: We report a dissonance between the genetic and chemical methods of ascertaining aflatoxigenicity. Fungi $(n=314)$ that were morphologically identified as $A$. flavus and A. parasiticus were isolated from maize kernels and soil from Eastern Kenya. The fungi were further characterized to confirm their identities using a PCR-sequence analysis of the internal transcribed spacer (ITS) region of rDNA which confirmed them to be Aspergillus species. We selected and induced 16 isolates in YES media amended with Dichlorvos to produce AFs. Seven of the sixteen isolates were DM-AM positive (aflatoxigenic) but lacked at least one of the key aflatoxin-associated genes. Even more confounding, $A$. flavus isolate (1EM2606) had all aflatoxin-associated genes but was non-aflatoxigenic (DV-AM negative) while $A$. flavus (1EM1901) having all genes was aflatoxigenic (DV-AM positive). The genetic abundance of the AF-asscociated genes among the isolates was as follows: aflQ (100\%), aflD (62.5\%) followed by $\operatorname{aflR}(37.5 \%)$ and $\operatorname{aflP}(25 \%)$.

Conclusion: We report that either method alone is limited in ascertaining aflatoxigenicity among Aspergillus section Flavi. The discordance between presence of aflatoxin-associated genes and aflatoxigenicity may be due to epigenetic factors that affect secondary metabolism, or even other signaling processes that alter toxin production that still remain poorly understood.

\section{Background}

Aspergillus species of the section Flavi are associated with production of aflatoxins thereby contaminating food material both in field and storage conditions. The congeneric species $A$. flavus and $A$. parasiticus are principal producers of aflatoxins [1] although to a lesser extent, other fungi within the genus may produce intermediates of aflatoxin synthesis which are equally harmful [2]. Consequently, information on Aspergillus species diversity [3], their capacity to produce aflatoxins and the type of toxins they produce [4] is critical in risk mitigation. The production of aflatoxins was first thought to be speciesspecific as some species produced the toxins (aflatoxigenic) while others did not (non-aflatoxigenic) [5]. However, there are recent findings suggesting variations in capacity to produce toxins even within Aspergillus species [6, 7]. For this reason, it is imperative to correctly identify Aspergillus species and characterize their aflatoxigenic potential prior to development of viable biological control products intended to reduce mycotoxin contamination of crops in the field $[5,8]$. 
Currently, researchers rely on diverse morphological, chemical and molecular techniques to segregate between aflatoxin producing and non-aflatoxin producing Aspergillus species in the section Flavi [3]. The choice of technique is largely determined by resource considerations mainly technical expertise, facilities and infrastructure [4]. The advancement of technology for identification of AF associated genes has greatly improved the accuracy with which species of Aspergillus have been classified as either aflatoxigenic or non-aflatoxigenic. However, genetic classification of aflatoxigenic potential of fungi remains a difficult task to accomplish [9] because at times results may show no significant correlation [4]. There are as many as $25 \mathrm{AF}$-genes in the cluster linked to aflatoxin production including: aflQ, aflD, affP, aflS, afIM, and affR, $[4,10]$ and addition to the list continues. Of interest currently is to find genes or sets of genes whether aflP and aflQ [9] or aflD and affS[11] that are sufficiently predictive of aflatoxigenic potential of fungi. This will greatly simplify the process of molecular assignment of toxigenicity for Aspergillus species [11]. However, recent analyses of genetic and metabolic profiles of Aspergillus isolates and their potential to produce AFs is still confounding and inconclusive within species tested [4, $9,10,12]$.

In the context of AF production among species of Aspergillus section Flavi, workers have advanced different hypotheses to explain the variations in their findings. The observed differences are thought to be occasioned on one hand, by epigenetic factors that alter developmental changes necessary for fungi to switch from normal vegetative growth (primary metabolism) to AF production (secondary metabolism) [13]. On the other hand, the location of the AF- gene cluster on the chromosome is thought to make it inaccessible to transcription factors hence, lack of a trigger for AF production [14]. Others postulate that $\mathrm{AF}$ production is due to existence of other genes, yet to be characterized, that could have a bearing on AF production [15-17]; or even presence of other poorly understood signaling processes that alter toxin production [13].

In general, the existing practice is to tag Aspergillus isolates as toxigenic or not, based on positive identification of AF- associated genes in the fungal genome or a positive chemical test conducted on actively growing fungi. The aim of the current study was to ascertain aflatoxigenicity by combining the two (PCR-genetic and chemical) methods. Data was generated using a set of four commonly cited aflatoxin-associated genes: aflD (nor-1), aflQ (ordA), aflP (omtA) and aflR (regulatory) and the recently developed Dichlorvos-Ammonia (DV-AM) methods for testing aflatoxigenicity. The implication of the findings is further discussed

\section{Results}

\section{Chemical test for aflatoxigenicity}

The chemical test showed that $56.25 \%$ (9 of 16) fungal isolates growing on DV-amended plates were aflatoxigenic producing a red coloration (positive test) following ammonia (AM) treatment. These were 8 A. flavus isolates (1EM1901, 2EM0502, 1EM4503, 2EM0602, 1EM4501, 2EM6103, 2EM3506 and 1EM4502) and 1 A. parasiticus (1EM0402) (Table 1 and Figure 1). Image analysis (Image $J$ software) 
revealed the color change occurred at the center of the plates for some isolates (Figure $1 \mathrm{~B}, \mathrm{C}$ ) while in others it occurred diffusely all over the entire plate (Figure $1 \mathrm{E}, \mathrm{F}$ ). In contrast, the remaining 7 culture plates that had no coloration were non-aflatoxigenic (negative test).

Table 1 Results of the Dichlorvos-Ammonia (DV-AM) method and genetic analysis

\begin{tabular}{|c|c|c|c|c|c|}
\hline & \multicolumn{5}{|c|}{ Genes } \\
\hline & \multirow{2}{*}{$\begin{array}{l}\text { DV-AM } \\
\text { Method }\end{array}$} & \multirow{2}{*}{$\begin{array}{c}\text { aflD } \\
(\text { nor-1) }\end{array}$} & \multirow{2}{*}{$\begin{array}{c}\text { aflQ } \\
(\operatorname{ord} A)\end{array}$} & \multirow{2}{*}{$\begin{array}{c}\text { aflP } \\
(o m t A)\end{array}$} & \multirow{2}{*}{$\begin{array}{c}\text { aflR } \\
\text { (regulatory) }\end{array}$} \\
\hline & & & & & \\
\hline 1EM1901 (A. flavus ) & + & + & + & + & + \\
\hline 2EM0402 (A. parasiticus ) & + & + & + & - & - \\
\hline 1EM1201 (A. flavus ) & - & + & + & - & - \\
\hline 1EM2901 (A. flavus ) & - & - & + & - & + \\
\hline 2EM0601 (A. parasiticus ) & - & + & + & - & + \\
\hline 2EM0502 (A. flavus ) & + & + & + & - & + \\
\hline 2EM3503 (A. flavus ) & - & - & + & - & - \\
\hline 2EM0501 (A. flavus ) & - & + & + & - & - \\
\hline 1EM4503 (A. flavus ) & + & + & + & - & - \\
\hline 2EM0602 (A. flavus ) & + & + & + & + & + \\
\hline 2EM1201 (A. flavus ) & - & + & + & - & + \\
\hline 1EM2606 (A. flavus ) & - & + & + & + & + \\
\hline 1EM4501 (A. flavus) & + & - & + & - & + \\
\hline 2EM6103 (A. flavus) & + & - & + & - & - \\
\hline 2EM3506 (A. flavus) & + & - & + & + & + \\
\hline 1EM4502 (A. flavus) & + & - & + & - & + \\
\hline
\end{tabular}

+ and - denotes the presence (positive) and absence (negative) respectively.

\section{Genetic analysis of aflatoxin gene clusters}

The genetic analysis showed that most of isolates had the aflatoxin-associated genes in their genome.

The abundance of the aflatoxin-associated genes was as follows: aflQ (ordA) (100\%), aflD (nor-1) (62.5\%), affR (regulatory) (37.5\%) and aflP (omtA) (25\%) (Table 1). There were variations in the genes 
among the species. Figure 2 is representative of gel image with the resolved bands of the respective aflatoxin-associated genes. aflD (nor-1), aflQ (ordA), aflP(omtA) and aflR genes were approximately $400 \mathrm{bp}, 750 \mathrm{bp}, 1000 \mathrm{bp}$ and $1200 \mathrm{bp}$ respectively. The biological functions of the selected aflatoxin-gene cluster are provided in Table 2.

Table 2 Selected aflatoxin-associated genes and their function

\begin{tabular}{|c|c|c|c|}
\hline Genes & Frequency & Enzyme encoded & Function \\
\hline aflQ $($ ordA $)$ & $(100 \%)$ & $\begin{array}{l}\text { Encodes } \\
\text { oxidoreductase }\end{array}$ & $\begin{array}{l}\text { Converts } O \text {-methylsterigmatocystin (OMST) and dihydro- } O \text { - } \\
\text { methylsterigmatocystin (DHOMST) to aflatoxins (B1, B2, } \\
\text { G1, and G2) [18]. }\end{array}$ \\
\hline aflD (nor-1) & $(62.5 \%)$ & $\begin{array}{l}\text { Norsolorinic acid } \\
\text { reductase }\end{array}$ & Converts norsolorinic acid to averantin [19]. \\
\hline aflP $(o m t A)$ & $(37.5 \%)$ & $O$-methyltransferase & $\begin{array}{l}\text { Conversion of sterigmatocystin (ST) to } O- \\
\text { methylsterigmatocystin (OMST) and } \\
\text { dihydrosterigmatocystin (DHST) to dihydro-O- } \\
\text { methylsterigmatocystin (DHOMST) [20]. }\end{array}$ \\
\hline $\begin{array}{c}\text { aflR } \\
\text { (Regulatory) }\end{array}$ & $(25 \%)$ & Regulatory gene & Activates aflatoxin transcription [21] \\
\hline
\end{tabular}

By assessing the results of the genetic and chemical method independently, it was possible to assign aflatoxigenicity or not, to the Aspergillus isolates. However, when the outputs of both methods were compared, the results were confounding. There was no consistent pattern to predict aflatoxigenicity from the genetic data. While the aflQ-ordA gene was present in all samples, it was not sufficient to predict aflatoxigenicity. In addition, the A. flavus isolate 1EM1901 had all the four genes and was toxigenic in both tests. By contrast, another A. flavus isolate 1EM2606 also had the four genes, but was nonaflatoxigenic in the DV-AM test. This dissonance was not only among A. flavus but also A. parasiticus. The $A$. parasiticus isolate 2EM0402 which had only two of the four genes of interest was toxigenic, while the conspecific $A$. parasiticus 2EM0601 with three of the four genes was non-aflatoxigenic.

\section{Discussion}

The ubiquitous soil borne fungi in the genus Aspergillus are free living but become of concern when they contaminate crops and produce aflatoxins presenting serious hazard to human and animal health and negatively affect trade. The premise of Biological Control (BC) of pre-harvest aflatoxin contamination by non-aflatoxigenic strains of $A$. flavus is that there will be competition that suppresses the fungus' ability to infect or produce aflatoxin [24]. A key element for the success of BC programs using Aspergillus species is correct identification of candidate fungal species and accurate prediction of their aflatoxigenicity and the nature of their interaction with other species. 
In the current study, the genetic and chemical methods of ascertaining aflatoxigenicity gave divergent results implying that the selected AF-genes could not predict (non-)aflatoxigenicity among tested Aspergillus species. Similarly, a negative DV-AM test did not predict presence or absence of AFassociated genes. This incongruence between the presence of AF- genes and aflatoxin production could not be explained. The DV-AM method has been reported successful in segregating aflatoxigenic and nonaflatoxigenic strains of $A$. flavus from Mexico [25]. The findings of the current study, to the best of our knowledge, demonstrate confounding results derived from an effort to predict aflatoxigenicity among Aspergillus species isolated from Eastern Kenya-a known aflatoxicosis hotspot.

Earlier work had proposed aflQ (ordA) and aflD (nor-1) to be ideal markers of aflatoxigenic potential [12, $23,26]$. On the contrary, our findings indicate the above genes are dominant among Aspergillus species but insufficient to assign (non-)aflatoxigenicity. This corroborates the work of Okoth, et al. [4] suggesting absence of correlation between the presence of AF-associated genes and the production of aflatoxins. An attempt to explain these variations may require in-depth investigation into the interaction of metabolic pathways that could interact with the AF biosynthetic pathway. This was not the scope of the current work. According to Price, et al. [21], the gene affR could regulate other genes outside the AF biosynthetic cluster driving AF production. The proximity of gene clusters is believed to influence the expression of adjacent genes. Price, et al. [21] linked the presence of the genes: hypB, nadA, hlyC, and niiA to the regulatory effect of aflR. In the current study, it may be difficult to assign an overarching role in aflatoxin production to the affR regulatory gene. This is because some non-aflatoxigenic isolates had the affR regulatory gene while other toxigenic that did not have it.

It is possible that other factors such as mutations in the AF-associated genes could affect aflatoxin production among species within section Flavi $[12,27]$. The existence of inter- and intra-specific mutations within the genes of interest likely affect target binding sites of the primers used [10,28]. However, that requires further investigation. We are inclined to concur with Okoth, et al. [4] and Oloo, et al. [11] that there is need to combine several methods such as: Chemical, Molecular (using more genes) and Metabolic profiling to establish aflatoxigenic potentials of fungi prior to their use as candidates for Biological Control programs.

\section{Conclusions}

It appears that the current preferred methods for ascertaining aflatoxigenicity do not converge sufficiently, due to unknown reasons. Resolution of this stalemate ought to have great implications on Biological control programs using non-aflatoxigenic Aspergillus species.

\section{Methods}

\section{Identification and culturing of fungi}


Aspergillus species used in this study were isolated from maize kernels collected in Eastern Kenya aflatoxicosis hot-spot [29]. The fungi were sub-cultured following standard protocols then identified to species level following morphological and colony characteristics using Aspergillus specific keys [30]. The selection of the fungi in this study was based on their isolation frequency from the maize samples. This gave a total of 16 most frequently isolated Aspergillus species. Molecular identification of the fungi was carried out using the Internal Transcribed Spacer (ITS1-5.8S-ITS2 cluster) regions of the ribosomal DNA gene cluster [4]. The fungi were then sub-cultured on Czapek Dox Agar medium (HiMedia Laboratories Pvt. Ltd), then incubated at $28^{\circ} \mathrm{C}$ for five days. The fungi were coded depending on the season and area of collection and maize sample number: A. flavus were coded as: [1EM1901, 1EM1201, 1EM2606, 1EM2901, 1EM4501, 1EM4501, 1EM4503, 2EM0501, 2EM0502, 2EM0602, 2EM1201, 2EM3503, 2EM3506, and 2EM6103] and A. parasiticus coded as: [2EM0402 and 2EM0601].

\section{Dichlorvos-ammonia (DV-AM) test for aflatoxigenicity}

For the DV-AM method, the fully grown isolates initially cultured on the Czapek Dox Agar medium were sub-cultured on aflatoxin-inducing Yeast Extract Sucrose (YES) medium (amended with 50mg/L streptomycin sulfate and penicillin, Zhonghuo Pharmaceuticals, China) and maintained for seven days at $28^{\circ} \mathrm{C}$. The culturing and testing for aflatoxigenicity of the isolates on the aflatoxin-inducing YES media was sequentially done following the protocols for the DV-AM method as described by [25]. The method briefly involved: (i) Dichlorvos diluted with methanol in 250 fold ratio (Amiran Kenya Ltd) was premixed with the media prior to solidification, (ii) the isolates were incubated in darkness at $28^{\circ} \mathrm{C}$ for 5 days, (iii) $0.2 \mathrm{~mL}$ of ammonium hydroxide solution was poured onto the inside of the lid of the petri dish plate used to set up the DV-AM method after the 5-day incubation period, (iv) the isolates were categorized as either aflatoxigenic or non-aflatoxigenic depending on their ability to produce aflatoxins (shown by a characteristic red coloration at the underside of the plates), and (v) the plate images of the aflatoxigenic isolates were further analyzed with Image J 1.x software for enhanced detection (Figure 1 C, F).

\section{Identification of aflatoxin-associated gene clusters}

The fungal isolates used for molecular identification were grown in Potato Dextrose Agar medium (PDA; $\mathrm{pH}$ 6.0) and maintained at $28{ }^{\circ} \mathrm{C}$ for five days. Afterwards, the periphery of the exponentially growing fungal mycelium (50-100 mg) was excised aseptically using a sterile scalpel. DNA extraction was done using Quick-DNA ${ }^{\text {TM }}$ Fungal/Bacterial Kit (Zymo Research). Finally, $100 \mu \mathrm{L}$ of DNA was eluted for amplification. Four aflatoxin-specific primers (Inqaba Biotechnical Industries (Pty) Ltd (South Africa)) were used to amplify genes ( $a f I D$, aflQ, and affP) encoding for enzymes involved in the aflatoxin biosynthesis and regulation (aflR) of the pathway (Table 3). The four genes selected for this study were chosen based on their direct role in the final production of aflatoxins as reported in the literature (Table 2).

Table 3 Aflatoxin-associated primer-pair combinations for Aspergillus species 


\begin{tabular}{|c|c|c|c|c|c|c|}
\hline $\begin{array}{l}\text { Primer } \\
\text { code }\end{array}$ & $\begin{array}{l}\text { Target } \\
\text { gene }\end{array}$ & Primer Sequences & References & $\mathrm{T}_{\mathrm{m}}$ & Purification & Modifications \\
\hline AflD- & \multirow{4}{*}{$\begin{array}{l}\text { aflD } \\
1)\end{array}$} & Nor1-F (5'-ACC GCT ACG CCG & \multirow[t]{4}{*}[22]{} & \multirow{4}{*}{$\begin{array}{l}74.42 \\
72.78\end{array}$} & \multirow{4}{*}{$\begin{array}{l}\text { Standard } \\
\text { Standard }\end{array}$} & \multirow{4}{*}{$\begin{array}{l}\text { None } \\
\text { None }\end{array}$} \\
\hline 1 for & & GCA CTC TCG GCA C-3') & & & & \\
\hline AflD- & & Nor1-R (5'-GTT GGC CGC CAG & & & & \\
\hline 2rev & & CTT CGA CAC TCC G-3') & & & & \\
\hline \multirow{2}{*}{$\begin{array}{l}\text { AflQ- } \\
1 \text { for }\end{array}$} & \multirow[t]{4}{*}{$\operatorname{afl} Q(\operatorname{ord} A)$} & Ord1-gF (5'-TTA AGG CAG CGG & \multirow[t]{4}{*}[23]{} & \multirow{4}{*}{$\begin{array}{l}58.35 \\
64.54\end{array}$} & \multirow{4}{*}{$\begin{array}{l}\text { Standard } \\
\text { Standard }\end{array}$} & \multirow{4}{*}{$\begin{array}{l}\text { None } \\
\text { None }\end{array}$} \\
\hline & & AAT ACA AG-3') & & & & \\
\hline AflQ- & & Ord1-gR (5'-GAC GCC CAA AGC & & & & \\
\hline 2rev & & CGA ACA CAA A-3') & & & & \\
\hline \multirow{2}{*}{$\begin{array}{l}\text { AflP- } \\
1 \text { for }\end{array}$} & \multirow[t]{3}{*}{ aflP $(o m t A)$} & AflP-1for (5'-AGC CCC GAA GAC & \multirow[t]{3}{*}[9]{} & 60.16 & Standard & None \\
\hline & & CAT AAA C-3') & & 60.16 & Standard & None \\
\hline $\begin{array}{l}\text { AflP- } \\
2 \mathrm{rev}\end{array}$ & & $\begin{array}{l}\text { AflP-2rev (5'-CCG AAT GTC ATG } \\
\left.\text { CTC CAT C- } 3^{\prime}\right)\end{array}$ & & & & \\
\hline \multirow{2}{*}{$\begin{array}{l}\text { AflR- } \\
1 \text { for }\end{array}$} & \multirow[t]{4}{*}{ aflR } & AflR-1for aflR (5'-AAG CTC CGG & \multirow[t]{4}{*}{ [9] } & \multirow{4}{*}{$\begin{array}{l}60.16 \\
60.16\end{array}$} & Standard & None \\
\hline & & GAT AGC TGT A-3’) & & & \multirow[t]{3}{*}{ Standard } & \multirow[t]{3}{*}{ None } \\
\hline AflR- & & AflR-2rev (5'-AGG CCA CTA AAC & & & & \\
\hline 2rev & & CCG AGT A-3') & & & & \\
\hline
\end{tabular}

During the reaction, a total reaction volume of $25 \mu \mathrm{L}$ consisting of $12.5 \mu \mathrm{L}$ of One Taq ${ }^{\circledR} 2 \mathrm{X}$ Master Mix (New England Biolabs), $0.2 \mu \mathrm{L}$ of DNA template (< $1000 \mathrm{ng}), 0.5 \mu \mathrm{L}(0.2 \mu \mathrm{M})$ of each (forward and reverse) of the primers and $9.5 \mu \mathrm{L}$ of nuclease-free water. The mixture was gently mixed by priming pipettor at least 4 times and spun prior to PCR. PCR tubes were transferred to a preheated thermocycler at $94{ }^{\circ} \mathrm{C}$ for 3 minutes followed 30 cycles consisting of 1 minute of denaturation at $94{ }^{\circ} \mathrm{C}, 1$ minute of annealing at $57^{\circ} \mathrm{C}$ and 1 minute of extension at $72{ }^{\circ} \mathrm{C}$. A final extension of 10 minutes at $72{ }^{\circ} \mathrm{C}$ and a storage temperature of $4{ }^{\circ} \mathrm{C}$ were considered. The PCR products were then subjected to gel electrophoresis using $1 \%$ agarose gel pre-cast with Ethidium Bromide. The optimized conditions for the process involved a constant supply of voltage (50 V (41mA)) for 75 minutes in a Trisborate-EDTA (TBE) buffer electrophoretic chamber. The gel was visualized using Automatic Gel Imaging System (Peiqing Science and Technology Co., Ltd).

\section{Statistical analysis}

All experiments were replicated thrice and data is presented in percentages for the parameters analyzed. ImageJ 1.x software was used for color enhancements in plates with fungal colonies.

\section{List Of Abbreviations}

AF(s): Aflatoxin(s)

DHOMST: Dihydro-0-methylsterigmatocystin 
OMST: 0-methylsterigmatocystin

ST: Sterigmatocystin

TBE: tris-borate-EDTA

YES: Yeast Extract Sucrose

ITS: Internal Transcribed Spacer

\section{Declarations}

\section{Acknowledgements}

Not applicable.

\section{Authors' contributions}

LKM: Performed the experiments, generated data and drafted the manuscript; MAO and FJT: Designed the research topic, sourced funding, supervised the project and reviewed the manuscript; HMM: Provided fungal molecular expertise, supervised the project, analyzed the data and reviewed the manuscript. All authors approved the final draft.

\section{Funding}

The analysis of samples was supported by the Canadian Government through the Grand Challenges Canada (Grant ID S7 0656-01-10).

\section{Availability of data and materials}

The datasets used and/or analysed during the current study are available from the corresponding author on reasonable request.

\section{Declarations}

Ethics approval and consent to participate

Not applicable.

\section{Consent for publication}

Not applicable.

\section{Competing interests}

The authors declare that they have no competing interests. 


\section{References}

1. Varga J, Frisvad JC, Samson R: Two new aflatoxin producing species, and an overview of Aspergillus section Flavi. Studies in Mycology 2011, 69:57-80.

2. Salano EN, Obonyo MA, Toroitich FJ, Odhiambo B, Omondi , Aman B, Omondi: Diversity of putatively toxigenic Aspergillus species in maize and soil samples in an aflatoxicosis hotspot in Eastern Kenya. African Journal of Microbiology Research 2016, 10(6):172-184.

3. Afzal H, Shazad S, Qamar S, Nisa S: Morphological identification of Aspergillus species from the soil of Larkana District (Sindh, Pakistan). Asian J Agric Sci 2013, 1(105):e17.

4. Okoth S, De Boevre M, Vidal A, Diana Di Mavungu J, Landschoot S, Kyallo M, Njuguna J, Harvey J, De Saeger S: Genetic and toxigenic variability within Aspergillus flavus population isolated from maize in two diverse environments in Kenya. Frontiers in Microbiology 2018, 9(57).

5. Cotty PJ, Antilla L, Wakelyn PJ: Competitive exclusion of aflatoxin producers: farmer driven research and development. Biological control: a global perspective 2007:241-253.

6. Lagat MK, Toroitich FJ, Obonyo MA: Development of an ELISA-based method for testing aflatoxigenicity and aflatoxigenic variability among Aspergillus species in culture. Scientific African 2020, 7:e00266.

7. Lagat MK, Toroitich FJ, Obonyo AM, Makonde HM: Modulation of Aflatoxin Production by Interaction of Aspergillus Species from Eastern Kenya. Journal of Environmental Science, Toxicology and Food Technology 2019.

8. Dawlatana M, Shahida S, Rahim M, Hassan MT: Investigation on the occurrence of ochratoxin A in maize in Bangladesh. Bangladesh Journal of Scientific and Industrial Research 2008, 43(4):495-500.

9. Fakruddin M, Chowdhury A, Hossain MN, Ahmed MM: Characterization of aflatoxin producing Aspergillus flavus from food and feed samples. SpringerPlus 2015, 4(1):159.

10. Gallo A, Stea G, Battilani P, Logrieco AF, Perrone G: Molecular characterization of an Aspergillus flavus population isolated from maize during the first outbreak of aflatoxin contamination in Italy. Phytopathologia Mediterranea 2012, 51(1):198-206.

11. Oloo RD, Okoth S, Wachira P, Mutiga S, Ochieng P, Kago L, Nganga F, Domelevo Entfellner J-B, Ghimire S: Genetic profiling of Aspergillus isolates with varying aflatoxin production potential from different maize-growing regions of kenya. Toxins 2019, 11(8):467.

12. Jamali M, Karimipour M, Shams-Ghahfarokhi M, Amani A, Razzaghi-Abyaneh M: Expression of aflatoxin genes aflO (omtB) and aflQ (ordA) differentiates levels of aflatoxin production by Aspergillus flavus strains from soils of pistachio orchards. Research in microbiology 2013, 164(4):293-299.

13. Bhatnagar D, Cary JW, Ehrlich K, Yu J, Cleveland TE: Understanding the genetics of regulation of aflatoxin production and Aspergillus flavus development. Mycopathologia 2006, 162(3):155-166.

14. Chiou C-H, Miller M, Wilson DL, Trail F, Linz JE: Chromosomal location plays a role in regulation of aflatoxin gene expression in Aspergillus parasiticus. Applied and environmental microbiology 2002, 
68(1):306-315.

15. Chang P-K, Horn BW, Dorner JW: Sequence breakpoints in the aflatoxin biosynthesis gene cluster and flanking regions in nonaflatoxigenic Aspergillus flavus isolates. Fungal Genetics and Biology 2005, 42(11):914-923.

16. Chang P-K, Horn BW, Dorner JW: Clustered genes involved in cyclopiazonic acid production are next to the aflatoxin biosynthesis gene cluster in Aspergillus flavus. Fungal Genetics and Biology 2009, 46(2):176-182.

17. Yu J, Chang P-K, Bhatnagar D, Cleveland TE: Cloning of a sugar utilization gene cluster in Aspergillus parasiticus. Biochimica et Biophysica Acta (BBA)-Gene Structure and Expression 2000, 1493(1-

2):211-214.

18. Yu J, Chang P-K, Ehrlich KC, Cary JW, Montalbano B, Dyer JM, Bhatnagar D, Cleveland TE: Characterization of the critical amino acids of Aspergillus parasiticus Cytochrome P-450 monooxygenase Encoded by ordA that is involved in the biosynthesis of aflatoxins B1, G1, B2, and G2. Applied and environmental microbiology 1998, 64(12):4834-4841.

19. Trail F, Chang P-K, Cary J, Linz JE: Structural and functional analysis of the nor $\mathbf{1}$ gene involved in the biosynthesis of aflatoxins by Aspergillus parasiticus. Applied and environmental microbiology 1994, 60(11):4078-4085.

20. Yu J, Chang P-K, Payne GA, Cary JW, Bhatnagar D, Cleveland TE: Comparison of the omtA genes encoding 0-methyltransferases involved in aflatoxin biosynthesis from Aspergillus parasiticus and $A$. flavus. Gene 1995, 163(1):121-125.

21. Price MS, Yu J, Nierman WC, Kim HS, Pritchard B, Jacobus CA, Bhatnagar D, Cleveland TE, Payne GA: The aflatoxin pathway regulator $A f I R$ induces gene transcription inside and outside of the aflatoxin biosynthetic cluster. FEMS Microbiology Letters 2006, 255(2):275-279.

22. Rodrigues $P$, Venâncio A, Kozakiewicz Z, Lima N: A polyphasic approach to the identification of aflatoxigenic and non-aflatoxigenic strains of Aspergillus section Flavi isolated from Portuguese almonds. International journal of food microbiology 2009, 129(2):187-193.

23. Sweeney MJ, Pàmies P, Dobson AD: The use of reverse transcription-polymerase chain reaction (RTPCR) for monitoring aflatoxin production in Aspergillus parasiticus 439. International Journal of Food Microbiology 2000, 56(1):97-103.

24. Huang C, Jha A, Sweany R, DeRobertis C, Damann KE: Intraspecific aflatoxin inhibition in Aspergillus flavus is thigmoregulated, independent of vegetative compatibility group and is strain dependent. PLoS One 2011, 6(8).

25. Kushiro M, Hatabayashi H, Yabe K, Loladze A: Detection of aflatoxigenic and atoxigenic mexican Aspergillus strains by the Dichlorvos-Ammonia (DV-AM) Method. Toxins 2018, 10(7):263.

26. Mahmoud MA: Detection of Aspergillus flavus in stored peanuts using real-time PCR and the expression of aflatoxin genes in toxigenic and atoxigenic $A$. flavus isolates. Foodborne pathogens and disease 2015, 12(4):289-296. 
27. Adhikari BN, Bandyopadhyay R, Cotty PJ: Degeneration of aflatoxin gene clusters in Aspergillus flavus from Africa and North America. AMB Express 2016, 6(1):62.

28. Levin RE: PCR detection of aflatoxin producing fungi and its limitations. International Journal of Food Microbiology 2012, 156(1):1-6.

29. Obonyo MA, Salano EN: Perennial and seasonal contamination of maize by aflatoxins in eastern Kenya. International Journal of Food Contamination 2018, 5(1).

30. Klich MA: Identification of common Aspergillus species. Centraalbureau voor Schimmelcultures 2002.

\section{Figures}



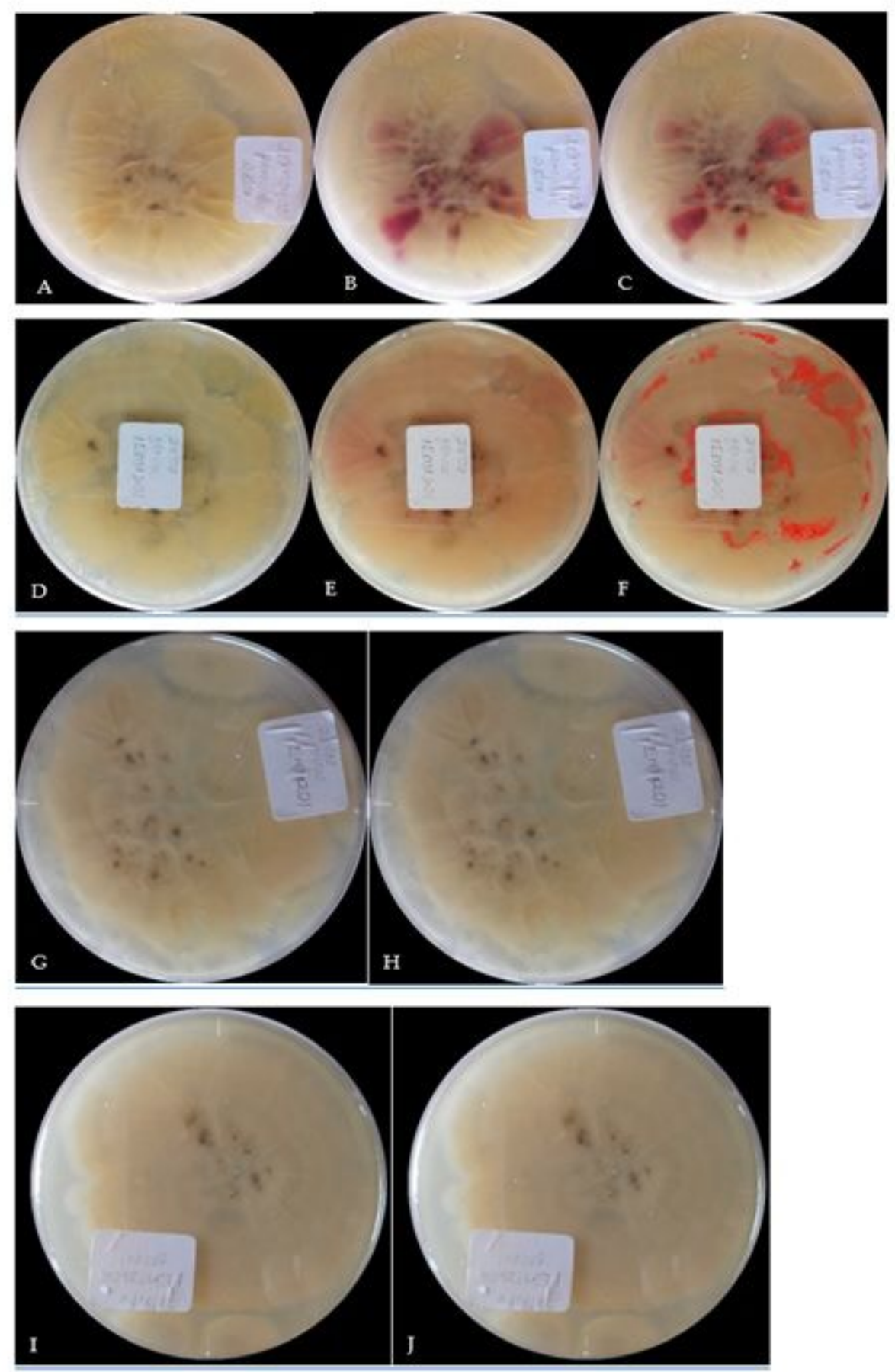

\section{Figure 1}

Dichlorvos-ammonia (DV-AM) method for aflatoxin detection in YES aflatoxin inducing media; (A) and (D) Fungal plates treated with Dichlorvos (DV) before ammonia (AM) treatment, (B) and (E) after ammonia treatment and (C) and (F) after ImageJ 1.x processing for isolates 2EM0402 and 1EM1901 respectively; $(\mathrm{G})$ and $(\mathrm{I})$ Fungal plates treated with DV before AM treatment and $(\mathrm{H})$ and $(\mathrm{J})$ after AM treatment for isolates 1EM1201 and 1EM2606 respectively. 

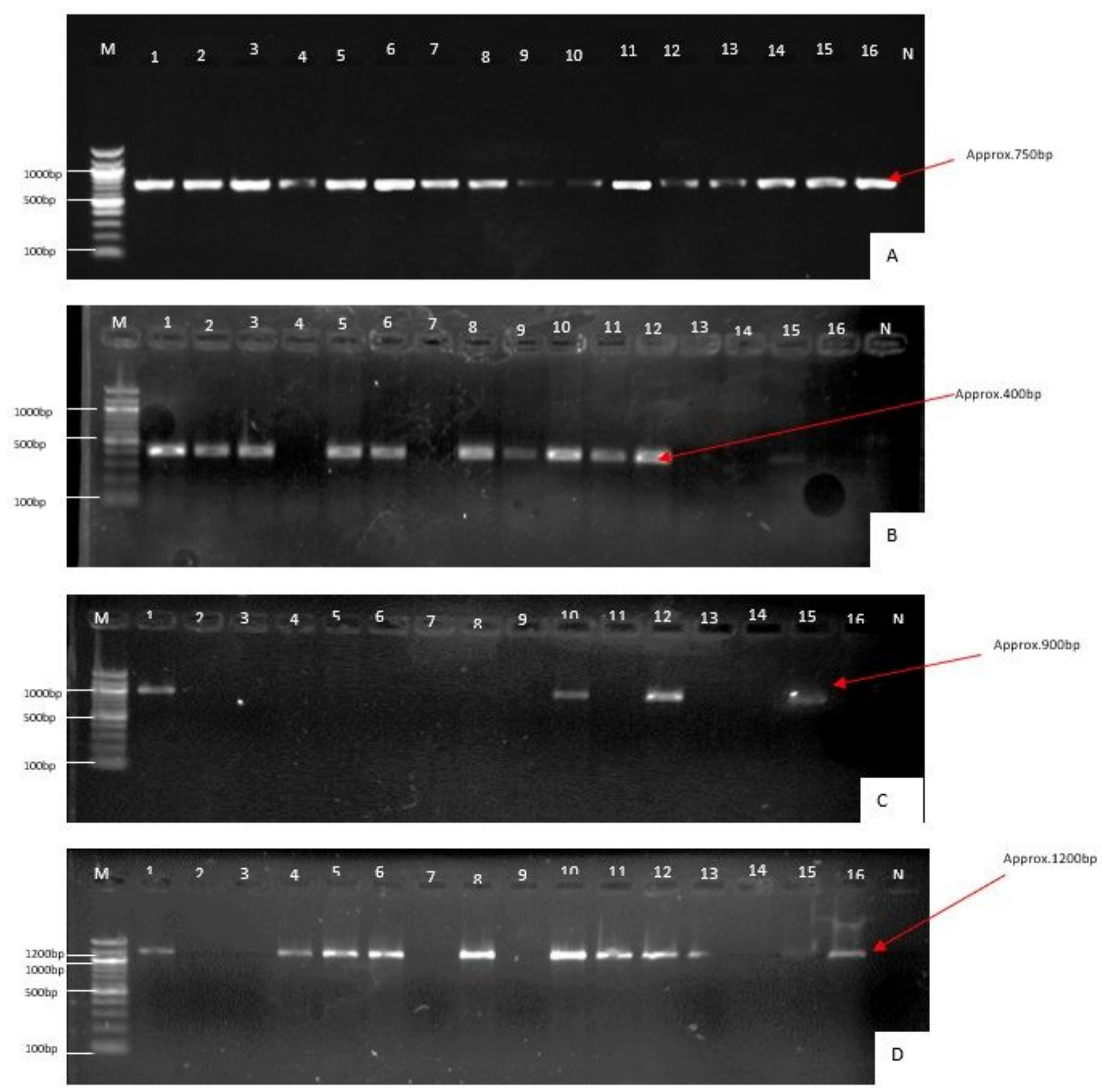

Figure 2

PCR products expressing the presence of aflQ (A), aflD (B), aflP (C) and AfIR (D) genes across the isolates. M- Molecular DNA 100 bp ladder (New England Biolabs); 1-1EM1901 (positive control) (A. flavus); 2- 2EM0402 (A. parasiticus); 3-1EM1201 (A. flavus); 4-1EM2901 (A. flavus); 5- 2EM0601 (A. parasiticus); 6-2EM0502 (A. flavus); 7-2EM3503 (A. flavus); 8-2EM0501 (A. flavus); 9-1EM4503 (A. flavus); 10-2EM0602 (A. flavus); 11-2EM1201 (A. flavus); 12-1EM2606 (A. flavus); 13- 1EM4501 (A. flavus); 14- 2EM6103 (A. flavus); 15-2EM3506 (A. flavus); 16-1EM4502 (A. flavus); N- Negative control 